\title{
Stable carbon and nitrogen isotopes and elemental composition and origin of organic matter from the Neogene Euphrates, Injana and Dibdibba formations in Iraq: discrimination between marine and terrestrial environments
}

\author{
Salih Muhammad AWADH ${ }^{1, *}$ \\ 1 University of Baghdad, Department of Geology, College of Science, P.O. Box 47182, Baghdad, Iraq
}

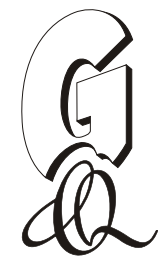

\begin{abstract}
Awadh, S.M., 2014. Stable carbon and nitrogen isotopes and elemental composition and origin of organic matter from the Neogene Euphrates, Injana and Dibdibba formations in Iraq: discrimination between marine and terrestrial environments. Geological Quarterly, 58 (4): 729-736, doi: 10.7306/gq.1174

Three Neogene sedimentary formations reflecting different depositional environments have been investigated for the purpose of diagnosing the isotopic source of the sedimentary organic matter and their palaeoenvironmental significance in discriminating between marine and terrestrial environments. One of these formations is composed of carbonate and marl of a shallow-marine environment (Euphrates Formation), and the other formations are composed of a clastic terrestrial (fluviatile) deposits with some differences in the depositional conditions (Injana and Dibdibba formations). The isotopic $\delta^{13} \mathrm{C} \%, \delta^{15} \mathrm{~N} \%$ values, organic carbon $(\mathrm{OC}$ ) and total nitrogen contents, and atomic $\mathrm{C} / \mathrm{N}$ ratios are used as evidence of depositional environment. Average $\delta^{13} \mathrm{C}$ values (in \%) for the Dibdiba, Injana and Euphrates formations are $-25.4,-25.7$ and -24.5 , respectively; average $\delta^{15} \mathrm{~N}$ values (in \%o) are 4.44, 5.24 and 7.24 and average OC (in wt.\%) is $0.13,0.3$ and 1.1 , respectively. A significant variation in the stable carbon and nitrogen isotope compositions between fluvial and marine deposits was recorded. The $\delta^{13} \mathrm{C}, \delta^{15} \mathrm{~N}$ and $\mathrm{C} / \mathrm{N}$ values indicate that the organic matter in the Euphrates Formation is of marine origin, whereas it is of terrestrial origin (fluviatile) in the Injana and Dibdibba formations. The $\mathrm{C} / \mathrm{N}_{\text {atomic }}$ values are mostly high in the Injana (37) and Dibddiba formations (51), suggesting greater input and/or preservation of terrestrial organic matter derived from land plants; the shallow-marine environment (Euphrates Formation) was characterized by a low C/N ratio (9) due to the algal-derived organic matter with limited input of terrestrial organic matter.
\end{abstract}

Key words: stable carbon isotopes, stable nitrogen isotopes, organic matter, marine environment, terrestrial environment, palaeoenvironment, Iraq.

\section{INTRODUCTION}

Organic matter $(\mathrm{OM})$ is present in all marine, continental and aquatic environments. Although continental margins account for only $10 \%$ of the total ocean area, more than $90 \%$ of all organic carbon burial occurs in sediments depositing on deltas, continental shelves, and upper continental slopes (Berner and Canfield, 1989). The origin of OM can be very different deriving variously from decomposition of land plants, mangroves, macrophytes, algae, phytoplankton, zooplankton, bacteria and archaea (Burdige, 2007). Stable isotope carbon and nitrogen composition have been used to trace pathways of organic matter among consumers in the different environments (Peterson and Howarth, 1987; Hesslein et al., 1992). OM important biomarker compounds may be lost due to extensive diagenetic processes, but the $\mathrm{C} / \mathrm{N}_{\text {atomic }}$ ratio and the $\delta^{13} \mathrm{C}$ value appear to undergo little change during diagenesis (Meyers, 1994). In phytoplankton, carbon and nitrogen isotopes vary spatially and temporally accord-

\footnotetext{
*E-mail: salihauad2000@yahoo.com
}

Received: January 27, 2014; accepted: April 14, 2014; first published online: June 18, 2014 ing to environmental conditions (Wada, 1980; Takahashi et al., 1990). The $\delta^{13} \mathrm{C}$ of plants is characterized according to $\mathrm{CO}_{2}$ assimilation systems reflecting C3-plants and C4-plants. The $\delta^{13} \mathrm{C}$ becomes high in an aquatic environment where $\mathrm{CO}_{2}$ diffusion is restricted (Sweeney et al., 1978; Wada et al., 1987). The $\delta^{15} \mathrm{~N}$ is closely correlated with forms of nitrogen as well as organic growth rates (Wada, 1980). C/ $\mathrm{N}_{\text {atomic }}$ ratios have often been used to distinguish between algal and land-plant origins of sedimentary organic matter (Prahl et al., 1980; Premuzic et al., 1982; Jasper and Gagosian, 1993). Carbon isotopic ratios are useful to distinguish between marine and continental plant sources of sedimentary organic matter and to identify organic matter from different types of land plants (Meyers, 1994). The organic $\mathrm{C} / \mathrm{N}_{\text {atomic }}$ ratios serve as useful indicators in elucidating the source of sediment organic matter (Andrews et al.,1998; Muller and Voss, 1999; Maksymowska et al., 2000). The source, depositional environment and palaeoenvironment of the Neogene Euphrates, Injana and Dibdibba formations in Iraq have been studied by many researchers (Al-Rawi and Sadik, 1981; Al-Dabbas et al., 2013). These studies provided conclusions about the depositional environment that broadly concided but were not identical. Accordingly, this issue from the geochemists point of view remains a question to be solved. In this paper three sedimentary formations (Euphrates, Injana and Dibdibba formations) at Anah and Karbala areas of Neogene age were studied (Fig. 1). 


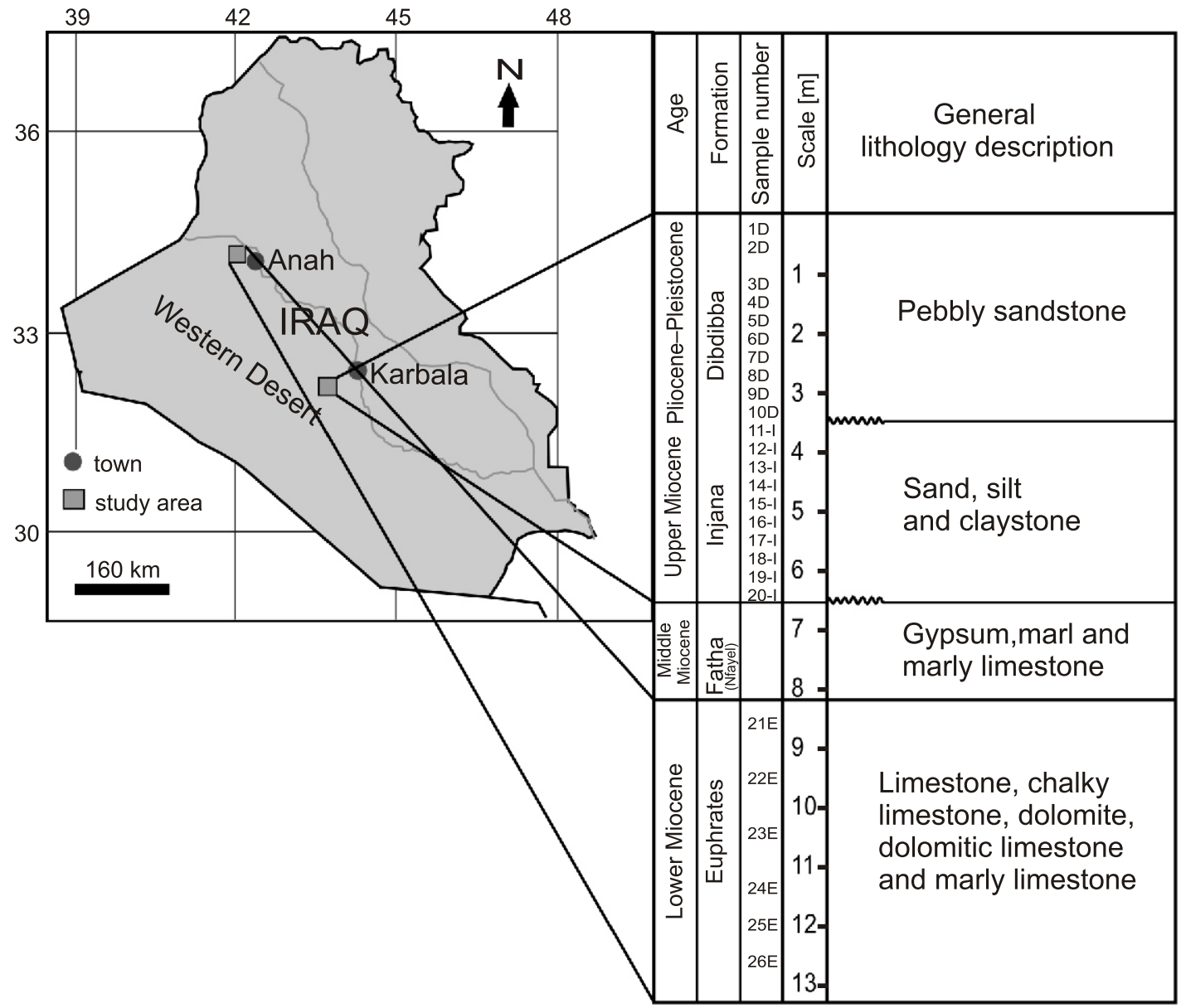

Fig. 1. Representative stratigraphic section and a simplified description of the formations in the study area

This paper uses organic $\mathrm{C}$ and $\mathrm{N}$ compositions in sedimentary strata for discriminating between marine to terrestrial environments. It is the first work on $\delta^{13} \mathrm{C}$ and $\delta^{15} \mathrm{~N}$, organic $\mathrm{C}$, organic $\mathrm{N}$ and $\mathrm{C} / \mathrm{N}$ values in the sedimentary formations of Iraq, as a contribution to interpreting the organic matter origin and type in the rock succession of the region.

\section{LITHOSTRATIGRAPHY AND DEPOSITIONAL ENVIRONMENT}

The successive formations from the Lower Miocene to the Pliocene-Pleistocene are illustrated in Figure 1. The Euphrates Formation, reflecting its wide distribution and relatively long stratigraphic range (all of the Early Miocene) was deposited in various conditions. It is composed at the type locality of shelly, chalky, well-bedded recrystallized limestones (Bellen et al., 1959), and has diverse lithology and fauna assemblages (Al-Hashimi and Amer, 1985) in the Karbala-Najaf region, and in the Southern Desert of Iraq (Al-Bassam, 1984). The age of this formation was suggested as the Early Miocene (Bellen et al., 1959; Prazak, 1974), and as late Early Miocene to early Middle Miocene (Cytroky and Karim, 1971a; Jassim and Karim, 1984; Al-Ghreri, 1985; Gayara and Taha, 1989). The Euphrates Formation is equivalent in age and lithology to the Hadrukh Formation of Saudi Arabia, and the Ghar Formation of Kuwait
(Mukhopadhyay et al., 1995). The Euphrates Formation represents deposition on a slowly subsiding marine shelf with an open to slightly restricted setting (Gayara and Taha, 1989). Its depositional environment in general is marine, warm tropical to subtropical; in central and northern Iraq, was deposited in a shallow-marine environment (Youkhanna, 1971). The Euphrates Formation in the Western Desert represent a shallow-marine environment, and in the middle and north of Iraq it reflects shallow-marine, reef and lagoonal conditions (Buday, 1980). The shoreline likely was near to Najaf in central Iraq rather than to Baghdadi in the west (Al-Dabbas et al., 2013). Al-Juboury (2009) suggested the derivation of the Injana Formation from nearby sources with contributions from igneous, metamorphic, and sedimentary provenance mainly in the highlands in the northeastern parts of Iraq which comprising mainly the Zagros Mountains and older sedimentary rocks. The source of Injana Formation is the high land in northern and northeastern Iraq. The depositional environment of this formation is variable: an initially lagoonal, then changing to a fluviolacustrine system (Buday and Jassim, 1987). It is widely exposed along cliffs in the north, middle and south of Iraq (Hassan et al., 2002), though absent of southwards, in the Basra area of Iraq, Saudi Arabia and Kuwait (Mukhopadhyay et al., 1995). Because the Dibdibba Formation is one of the youngest formations in Iraq, it has almost no subsurface distribution. The Dibdibba Formation, in the type locality, mainly consists of sandstone and gravel derived from igneous rocks, including pink granite, dolerites to- 
gether with white quartz; not infrequently the rock is strongly cemented. The Dibdibba Formation, in the type locality, is underlain conformably by the Fatha Formation (Bellen et al., 1959). In the middle of Iraq, the Dibdibba Formation is underlain unconformably by the Injana Formation. Its base is at the first appearance of sandstone or pebbly sandstone (Hassan et al., 2002). It is also recognized in Kuwait. In Saudi Arabia similar facies are included within the Hofuf Formation and partly in the Kharj Formation (Powers et al., 1966). The Dibdibba Formation represents extensive fluvial sedimentation probably as large old alluvial fans; it seems that at least two such fans may have been present (Jassim and Goff, 2006; cf. Al-Rawi and Sadik, 1981; Al-Ankaz, 2012; Awadh et al., 2013).

\section{MATERIALS AND METHODS}

\section{STUDY AREA AND SAMPLING}

Sampling was performed in two sites located in Anah and Karbala within the Stable Shelf on the eastern edge of the Western Desert (Fig. 1). Twenty six samples were collected from three different geological formations ranging in age from Early Miocene to Pliocene-Pleistocene. Sampling sites, lithology description, formation thicknesses and their ages are shown in Figure 1. Six samples were collected from a section exposing shallow-water limestone in the Euphrates Formation near the type locality (Anah) in the western part of Iraq. Twenty clastic samples were collected from an accessible section of the Injana and Dibdibba formations in central Iraq, near Karballa (ten samples from each formation).

\section{STABLE ISOTOPE ANALYSIS}

All samples were shipped and later analysed at the Stable Isotope Laboratory of the University of Missouri in Kansas City (USA). A small portion of each sample was used to determine the elemental and stable isotope compositions of bulk sample organic material. Samples were powdered and homogenized. For determining isotopes, $\mathrm{OC}$ and $\mathrm{TN}$, carbonates were removed by treating samples with $4 \mathrm{~N} \mathrm{HCl}$. Subsequently, samples were rinsed with deionized water to remove salts and then dried. The carbonate-free samples were then analysed for weight percent OC and TN on a Vario EL-III elemental analyzer. Duplicate analyses of each sample were run, and the mean of the two measurements is reported here. Replicate analysis of one sample $(n=5)$ gave a $1 \sigma$ precision of $\pm 0.02 \mathrm{wt} . \% C$ and \pm 0.003 wt. $\% \mathrm{TN}$. Isotope ratios were expressed as parts per thousand $(\% \circ)$ differences from a standard reference material:

$$
\delta=\frac{R_{\text {sample }}-R_{\text {reference }}}{R_{\text {reference }}} \times 1000
$$

where: $\delta(\%)$ stands for $\delta^{13} \mathrm{C}$ or $\delta^{15} \mathrm{~N}$, and $R_{\text {sample }}$ and $R_{\text {reference }}$ are the isotopic ratios $\left({ }^{13} \mathrm{C} /{ }^{12} \mathrm{C}\right.$ or $\left.{ }^{15} \mathrm{~N} /{ }^{14} \mathrm{~N}\right)$ of the sample and reference, respectively.

The Pee Dee Belemnite (PDB) was a reference for carbon, where $R\left({ }^{13 / 12} \mathrm{C}\right)$ VPDB $=0.01117960$ (Coplen, 2011), and was established as a $\delta^{13} \mathrm{C}$ value of zero; and atmospheric $\mathrm{N}_{2}\left(\delta^{15} \mathrm{~N} 0 \%\right)$ was a reference for nitrogen. The Spectrometer Stable Isotope Analyser with unit Solid/Liquid preparation mod- ule was operated in dual mode allowing ${ }^{13} \mathrm{C} /{ }^{12} \mathrm{C}$ and ${ }^{15} \mathrm{~N} /{ }^{14} \mathrm{~N}$ to be measured simultaneously. The standard deviation of isotopic determination ( $\mathrm{C}$ and $\mathrm{N}$ ) was less than $0.2 \%$, estimated from internal standards analysed along with the samples. The calibration and assessment of the reproducibility and accuracy of the isotopic analysis were based on replicate analyses of laboratory standard materials and international reference materials. Reproducibility based on triplicate analyses of the sample was $\pm 0.2 \%$ ofor $\delta^{13} \mathrm{C}$ and $\pm 0.3 \%$ ofor $\delta^{15} \mathrm{~N}$.

\section{RESULTS}

The $\mathrm{C} / \mathrm{N}_{\text {atomic }}$ values in the Euphrates Formation vary between 7.6 and 12.1 with an average of 9.0; in the Injana Formation ranges from 28 to 50 with an average of 37 ; and it varies between 40 and 63.6 with an average of 50.6 in the Dibdibba Formation (Table 1). Variations in $\delta^{13} \mathrm{C}, \delta^{15} \mathrm{~N}, \mathrm{OC}, \mathrm{TN}$ and $\mathrm{C} / \mathrm{N}_{\text {atomic }}$ are illustrated in Figure 2. The significant variation reflects different depositional environments. It is very clear here, that the carbonates of the Euphrates Formation are characterized by little variation in the value $\mathrm{C} / \mathrm{N}$, while the clasts of the Injana and Dibdibba formations are characterized by wide variation.

The carbon and nitrogen contents reflect lithology and grain size. Low contents of $\mathrm{OC}$ and TN were found within the fine fraction, but the coarse fraction contains fairly high amounts organic matter. This might be related to permeability. The ranges and averages of $\delta{ }^{13} \mathrm{C}$ showed stratigraphic variation: the clays, silty clays and sands of the Injana Formation gave -28.0 to $-23.3 \%$ o $(-25.7 \%$ ); the silt, sand and pebbly sand of the Dibdibba Formation gave -22.2 to $-28.1 \%(-25.4 \%$ o). These values were slightly lower than those of the limestones, dolomitic and marly limestones of the Euphrates Formation which underlies the Injana Formation which gave -25.8 to $-23.6 \%$ o $(-24.5 \%$ ). The organic matter from marine and continental sources ranged between -25.5 and $-21.5 \%$ (Prahl et al., 1994). The coarse fraction (pebbly medium to coarse sands of the Dibdibba Formation) had the lowest values of $\delta^{13} \mathrm{C}(28.1 \%)$ and $\delta^{15} \mathrm{~N}(3.99 \%)$, whereas the highest values of $\delta^{13} \mathrm{C}(-22.2 \%)$ and $\delta^{15} \mathrm{~N}(4.23 \%$ ) were in the fine fraction (silty to very fine sand).

In the carbonates of the Euphrates Formation, the $\delta^{13} \mathrm{C}$ varies from -25.8 to $-23.7 \%$ with an average of $-24.5 \%$, while for $\delta^{15} \mathrm{~N}$ values were 5.22 to $7.85 \%$ with an average of $7.24 \%$. Variation in the content of organic matter is very slight (Fig. 2). There is a relative homogeneity of $\delta^{13} \mathrm{C}$ values, except for the marly limestone sample (21E), and ahomogeneity of $\delta^{15} \mathrm{~N}$ values with the exception of dolomitic marly limestone. It is clear that sample $21 \mathrm{E}$ contains much OC and TN, and there is little in sample 25E. This suggests difference in organic content ( $\mathrm{C}$ and $\mathrm{N})$ based on lithology, where OC and TN are high in sample 21E (marly limestone), and low in sample 25E (dolomitic marly limestone). Dolomitization may hence affect organic preservation (Table 1). Carbonates of the Euphrates Formation show little differentiation of its content of organic matter in comparison to the clastic materials of the Dibdibba and Injana formations. Probably, this is a signal of the quality of organic matter preservation in marine as opposed to terrestrial conditions.

\section{INTERPRETATION AND DISCUSSION}

Algae are a common source of organic matter in marine and lacustrine, whereas plants are dominant in terrestrial environ- 
Values of $\delta^{13} \mathrm{C}, \delta^{15} \mathrm{~N}$, organic carbon and nitrogen of primary organic matter sources in sediments of the Euphrates, Injana and Dibdibba formations in Iraq

\begin{tabular}{|c|c|c|c|c|c|c|c|c|}
\hline $\begin{array}{c}\text { Sample } \\
\text { no. }\end{array}$ & Formation & Age & Lithology & $\begin{array}{l}\delta^{13} \mathrm{C} \\
{[\% 0]}\end{array}$ & $\begin{array}{l}\delta^{15} \mathrm{~N} \\
{[\%]}\end{array}$ & $\begin{array}{c}\mathrm{OC} \\
{[\mathrm{wt} \%]}\end{array}$ & $\begin{array}{c}\mathrm{TN} \\
{[\mathrm{wt} . \%]}\end{array}$ & $\mathrm{C} / \mathrm{N}_{\text {atomic }}$ \\
\hline 1D & \multirow{10}{*}{ Dibdibba } & \multirow{10}{*}{$\begin{array}{l}\text { Pliocene- } \\
\text { Pleistocene }\end{array}$} & silt in most & -23.7 & 5.14 & 0.01 & 0.0002 & 50.0 \\
\hline $2 \mathrm{D}$ & & & silt with very fine sand & -22.2 & 4.23 & 0.04 & 0.0010 & 40.0 \\
\hline $3 \mathrm{D}$ & & & silty with medium sand & -25.8 & 3.93 & 0.15 & 0.0033 & 45.6 \\
\hline $4 \mathrm{D}$ & & & pebbly medium to coarse sand & -26.6 & 3.52 & 0.15 & 0.0028 & 53.6 \\
\hline $5 \mathrm{D}$ & & & medium coarse to very coarse sand & -27.6 & 4.65 & 0.21 & 0.0046 & 45.6 \\
\hline $6 \mathrm{D}$ & & & $\begin{array}{l}\text { fine, medium coarse and very coarse sand } \\
\text { with little pebbles }\end{array}$ & -24.3 & 4.81 & 0.23 & 0.0045 & 51.1 \\
\hline 7D & & & $\begin{array}{l}\text { mostly very coarse sand with gravels } \\
\text { and pebbles }\end{array}$ & -24.1 & 4.80 & 0.10 & 0.0018 & 55.6 \\
\hline $8 \mathrm{D}$ & & & pebbly fine, medium to coarse sand & -24.2 & 5.73 & 0.10 & 0.0025 & 40.0 \\
\hline 9D & & & pebbly medium to coarse sand & -28.1 & 3.99 & 0.23 & 0.0038 & 60.5 \\
\hline $10 \mathrm{D}$ & & & pebbly coarse sand & -27.2 & 3.66 & 0.07 & 0.0011 & 63.6 \\
\hline \multicolumn{4}{|l|}{ Average } & -25.4 & 4.44 & 0.13 & 0.0026 & 50.6 \\
\hline 11- & \multirow{10}{*}{ Injana } & \multirow{10}{*}{$\begin{array}{l}\text { Upper } \\
\text { Miocene }\end{array}$} & clay in most with minor silt & -24.5 & 6.11 & 0.13 & 0.0039 & 33.0 \\
\hline $12-$ - & & & clayey siltstone & -27.3 & 4.92 & 0.15 & 0.0041 & 36.0 \\
\hline $13-1$ & & & clay sand & -25.2 & 5.54 & 0.26 & 0.0061 & 42.0 \\
\hline | & & & sandy silt & -26.1 & 4.26 & 0.20 & 0.0066 & 30.0 \\
\hline 15-I & & & friable sandy siltstone & -24.7 & 5.33 & 0.53 & 0.0189 & 28.0 \\
\hline 16-I & & & friable sandstone & -26.3 & 4.98 & 0.44 & 0.0125 & 35.0 \\
\hline $17-$ - & & & clayey medium to coarse sand & -23.8 & 6.33 & 0.39 & 0.0118 & 33.0 \\
\hline 18- & & & mostly friable clayey siltstone & -27.8 & 4.74 & 0.28 & 0.0062 & 45.0 \\
\hline 19- & & & medium to coarse sand & -28.0 & 4.88 & 0.41 & 0.0107 & 38.0 \\
\hline 20-I & & & medium to very coarse in most & -23.3 & 5.36 & 0.19 & 0.0038 & 50.0 \\
\hline \multicolumn{4}{|l|}{ Average } & 25.7 & 5.24 & 0.30 & 0.0085 & 37.0 \\
\hline $21 \mathrm{E}$ & \multirow{6}{*}{ Euphrates } & \multirow{6}{*}{$\begin{array}{l}\text { Lower } \\
\text { Miocene }\end{array}$} & marly limestone & -25.8 & 7.65 & 1.86 & 0.25 & 7.6 \\
\hline $22 \mathrm{E}$ & & & limestone with chalky limestone & -23.7 & 7.49 & 0.72 & 0.08 & 8.9 \\
\hline $23 \mathrm{E}$ & & & limestone to marly limestone & -24.1 & 7.64 & 0.95 & 0.11 & 8.6 \\
\hline $24 \mathrm{E}$ & & & chalky dolomitic limestone & -24.0 & 7.58 & 0.88 & 0.10 & 8.8 \\
\hline $25 \mathrm{E}$ & & & dolomitic marly limestone & -24.9 & 5.22 & 0.14 & 0.01 & 12.1 \\
\hline $26 \mathrm{E}$ & & & marly, chalky limestone & -24.6 & 7.85 & 1.87 & 0.23 & 8.1 \\
\hline \multicolumn{4}{|l|}{ Average } & -24.5 & 7.24 & 1.1 & 0.13 & 9.0 \\
\hline
\end{tabular}

$\mathrm{OC}$ - organic carbon; TN - total nitrogen

ments. Marine and lacustrine algae show a limited values of $\mathrm{C} / \mathrm{N}$ by comparison with land plants. Hence terrestrial and marine environments can be distinguished based on $\mathrm{C} / \mathrm{N}$ and $\delta^{13} \mathrm{C}$ values in organic matter.

The $\delta^{13} \mathrm{C}, \delta^{15} \mathrm{~N}, \mathrm{OC}, \mathrm{TN}$, and $\mathrm{C} / \mathrm{N}_{\text {atomic }}$ values of sediments are expected to be modified during subsequent early diagenesis, but the $\mathrm{C} / \mathrm{N}$ source signal appears to be preserved, and, in subaqueous sediments. During vertical sinking, dead phytoplankton, zooplankton biomass, and fecal pellets may undergo substantial. While a refractory background fraction of organic remains relatively stable in concentration with depth (Eadie et al., 1984).
Organic matter has been well-preserved within carbonates of the Euphrates Formation with little variation due to the quiet and non-turbulent environment. Though $\mathrm{OC}$ and TN were affected in the dolomitized sample. Organic matter has been preserved within the Injana and Dibdibba formations with high variation due to fluctuation of sedimentary conditions and in the amount of supply of organic matter from the land. During diagenesis, sediment may preserve source information in the $\mathrm{C} / \mathrm{N}$ and $\delta^{13} \mathrm{C}$ values. Despite the extensive early diagenetic losses of organic matter, the $\mathrm{C} / \mathrm{N}$ ratio and the $\delta^{13} \mathrm{C}$ appear to undergo little change (Meyers, 1994), and mass organic matter stabilization by adsorption (Tiessen et al., 1984). 


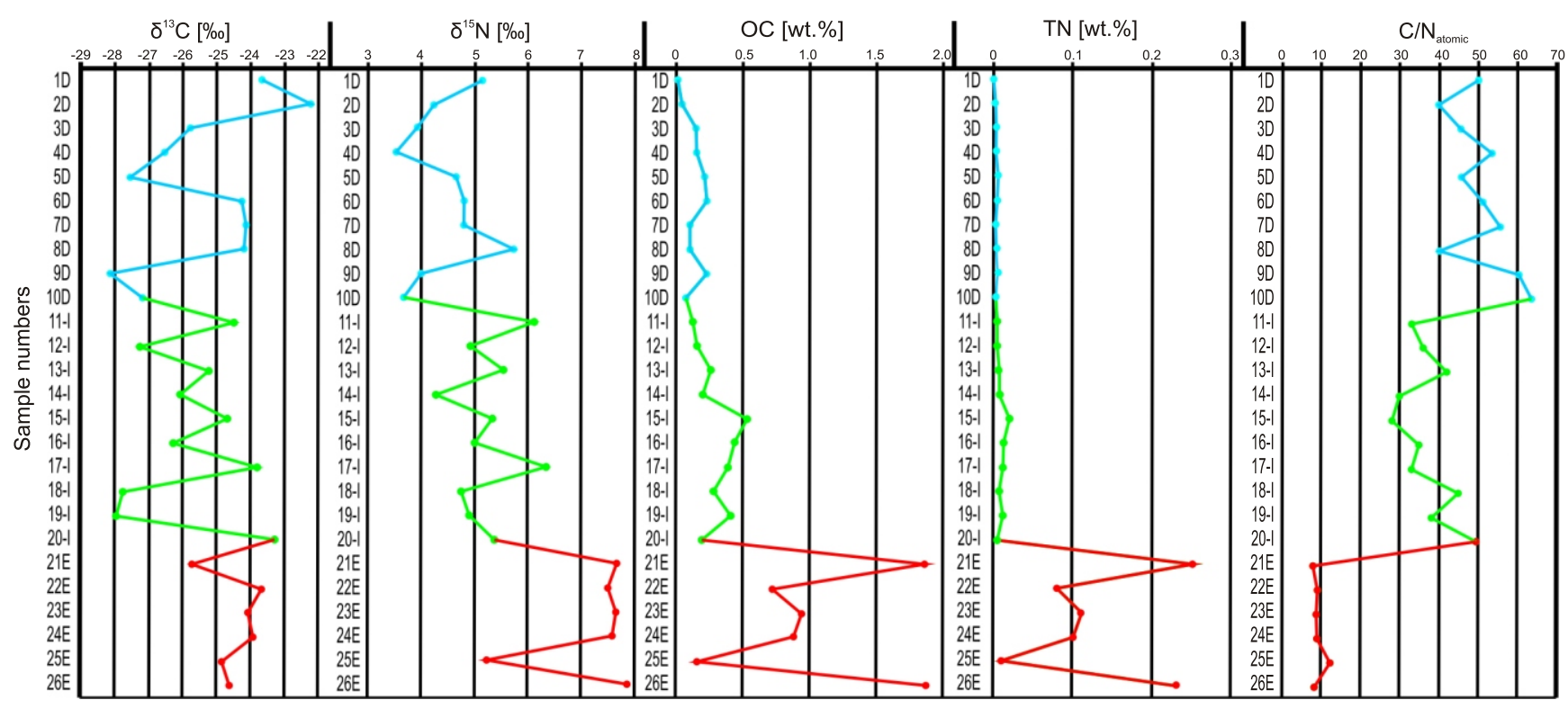

Fig. 2. Stable carbon and nitrogen isotope signatures, organic carbon, total nitrogen and atomic $\mathrm{C} / \mathrm{N}$ ratios of sediments from the Euphrates (red color), Injana (green color) and Dibddiba (blue color) formations

The average of $\mathrm{C} / \mathrm{N}_{\text {atomic }}$ ratios in the Euphrates Formation is much less than those in the Injana and Dibdibba formations (Fig. 2). This variation is due to the absence of cellulose in algae and its abundance in vascular plants, while algae are dominant in the marine environment, and vascular plants are common in the continental environment. $\mathrm{C} / \mathrm{N}_{\text {atomic }}$ values ranging between 30 and 40 in vascular plant debris have been isolated from coastal marine sediments, while being characteristic of cellulosic plants (Ertel and Hedges, 1985). Lignin and cellulose are good tracers for vascular land-plant biomass (Heaton, 1999). A high value of the $\mathrm{C} /$ Natomic $\mathrm{ra}_{\text {tio }}(>30)$ characterizes vascular plant debris (Hedges and Mann, 1979), and sediments enriched in vascular plant remains and therefore they contain $\mathrm{C} / \mathrm{N}_{\text {atomic }}$ value greater than 30 (Keil et al., 1994, 1998). The deposits on offshore slope and basin marine have yielded average $\mathrm{C} / \mathrm{N}$ values between 9 and 11 (Prahl et al., 1994).

The low concentration of nitrogen is the most important characteristic of the depositional environment of the Injana and Dibdibba formations, contrasting with the conditions of the Euphrates depositional environment. The amount of OC and TN in the Euphrates Formation appears higher than those in the Injana and Dibdibba formations, but the lowest ratio of $\mathrm{C} / \mathrm{N}$ was recorded in the Euphrates Formation (Table 1 and Fig. 2). Variability in $\mathrm{C} / \mathrm{N}$ values may reflect changes in the proportions of different types and amounts of marine algae. A very distinct variation in averages of $\mathrm{C} / \mathrm{N}$ ratios in the Euphrates Formation (9), The Injana Formation (37) and Dibddiba Formation (50.6) provides with convincing environmental evidence.

The palaeoenvironment of the Injana and Dibdibba formations may have involved thriving land plants, but a combination of erosion, slow burial and slow sedimentation rates contributed to the loss of a large portion of the organic matter. Carbon isotopic values are similar in the Injana and Dibdibba formations, and differ from that of the Euphrates Formation

$\mathrm{C} / \mathrm{N}$ ratios, and $\delta^{13} \mathrm{C}$ and $\delta^{15} \mathrm{~N}$ values have been widely used as effective markers to estimate the relative proportions of terrigenous and marine organic matter in coastal and marginal sediments (Meyers, 1997; Naidu et al., 2000; Stein and Mac- donald, 2004). River networks of tightly linked with the landscape played an essential role in transporting and depositing sediment of the Injana and Dibdibba formations, with land plants supplying the organic matter. While algae left a clear imprint in the sediments of the Euphrates Formation indicating a shallow-marine deposition environment. Spatial variation in sediment $\mathrm{C} / \mathrm{N}, \delta^{13} \mathrm{C}$ and $\delta^{15} \mathrm{~N}$ was recognized. It is generally assumed that land plants and marine algae have different organic $\mathrm{C} / \mathrm{N}_{\text {atomic }}$ ratios; cellulose- and lignin-rich vascular land plants have higher $\mathrm{C} / \mathrm{N}_{\text {atomic }}$ ratios (>15), whereas marine protein-rich algae have lower $\mathrm{C} / \mathrm{N}_{\text {atomic }}$ ratios $(<6)$ (Hu et al., 2006). Therefore, the increasing trend in $\mathrm{C} / \mathrm{N}$ from the bottom to the top (Fig. 2) is attributed to the marine regression, this being very clear in samples $21 \mathrm{E}$ to $26 \mathrm{E}$ from the Euphrates Formation which were deposited in a shallow-marine environment, but samples 1D to $10 \mathrm{D}$ and $11-\mathrm{I}$ to $20-\mathrm{I}$ with high $\mathrm{C} / \mathrm{N}$ ratios reflect land plants input and eventually indicate that the Injana and Dibdibba formations are of continental origin deposited in a fluviatile environment.

Terrestrial organic matter is often depleted in $\delta^{15} \mathrm{~N}$ (3 to $6 \%$ with an average of $4.8 \%$ relative to marine nitrogen; Sigman et al., 2000) and aquatic environments can typically maintain a higher $\delta^{15} \mathrm{~N}$ value than terrestrial environments (Petersen and Fry, 1987). The average $\delta^{15} \mathrm{~N}$ of all plant materials in the lagoon was $8.6 \pm 3.6 \%$ (average $\pm S D, n=7$; Wada et al., 1993). The origin of organic matter in sediments can be diagnosed using stable carbon and nitrogen isotopes following Meyers (1994) who recognized four distinctive suites in plants.

The relationship between $\delta^{13} \mathrm{C}$ and $\mathrm{C} / \mathrm{N}$ values indicates that the Injana and Dibdibba sediments occupied the isotopic ends of the known range for C3-terrestrial plants, the average of which suggested by Meyers (1994) ranges approximately between -27 to $-22 \%$, while most of the Euphrates samples fell into the field that indicates a marine algal source with the exception of one sample which fell into the lacustrine field and other sample outside the fields that indicate reworking processes (Fig. 3). 


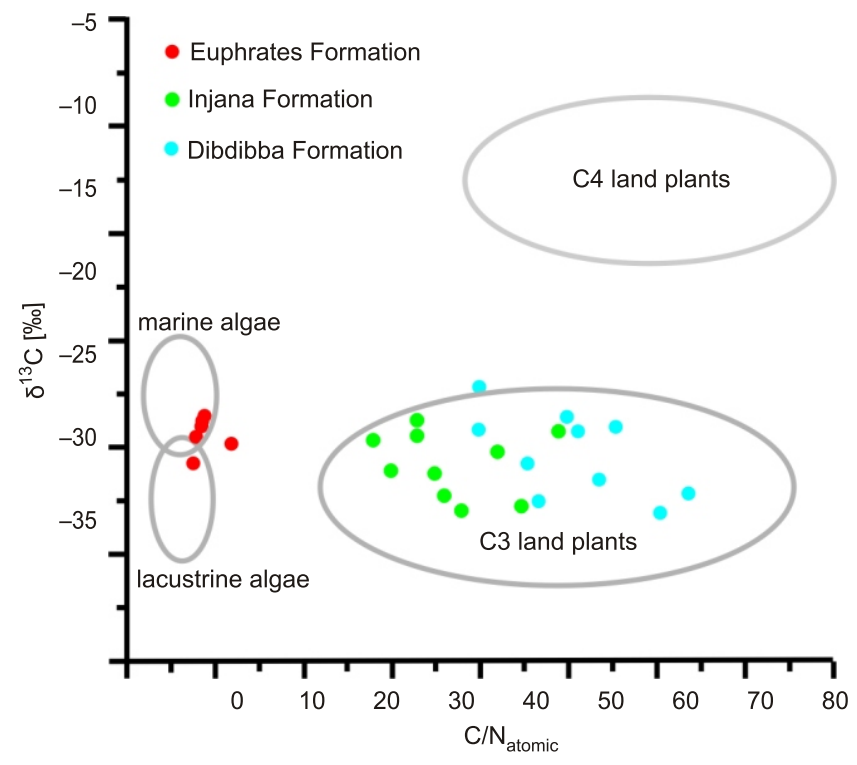

Fig. 3. Distinctive source combinations of atomic $\mathrm{C} / \mathrm{N}$ ratios and organic $\delta^{13} \mathrm{C}$ values of the Euphrates, Injana and Dibdibba formations

Sources of data are given in Table 1; fields after Meyers (1994)

CAM plants made an insignificant contribution to the formations studied because their production of organic debris is very small or non-existent by comparison to $\mathrm{C} 3$ and $\mathrm{C} 4$ plants, which deposit large amounts of leaf, branches, wood, and roots. However, CAM plants have the potential to be important sources of organic matter in specialized environments where they may be the dominant form of vegetation. CAM plants are those which utilize the Crassulacean acid metabolism as an adaptation to arid conditions. However, the sedimentary environment of the Euphrates Formation is marine; the Dibdibba and Injana formations are fluviatile, and the climate during sedimentation (Miocene and Pleistocene) suggests a rarity of CAM. Figure 3 clearly illustrates that C3 land plants were a source of organic matter in Injana and Dibdibba formations, whereas marine algae were a source for the Euphrates Formation.

\section{CONCLUSIONS}

Stable carbon and nitrogen isotope signatures in organic matter in sediments represent a common proxy for discriminating between depositional environments. These stable isotope compositions along with the total organic carbon and total organic nitrogen exist in different ratios indicating different organic matter origin. The distributions of $\delta^{13} \mathrm{C}, \delta^{15} \mathrm{~N}, \mathrm{TOC}, \mathrm{TN}$ in the Injana and Dibdibba formations are broadly similar, but they differ from those of the Euphrates Formation. The high $\mathrm{C} / \mathrm{N}$ contents and depleted organic $\mathrm{N}$ values in the Injana and Dibdibba formations indicate higher terrestrial particulate organic matter content. The $\delta^{13} \mathrm{C}$ values of the Euphrates deposits ( -25.8 to $-23.7 \%$ ) with enriched organic $\mathrm{N}$ indicate that the sedimentary organic matter is derived from marine algae. An increase in organic carbon in the Euphrates Formation may be due to a partial contribution from terrestrial plants suggesting a shallow-depositional environment. The sediments of the Dibdibba Formation in southern Iraq and Kuwait, and of the Hofuf Formation in Saudi Arabia were mainly supplied from an uplifted stable shelf where land plants were common. Despite the Injana and Dibdibba formations being deposited in a fluviatile environment, variations in $\delta^{13} \mathrm{C}$ and $\delta^{15} \mathrm{~N}$ values. The $\delta^{13} \mathrm{C}_{\text {org }}$ and $\delta^{15} \mathrm{~N}$ values in the Injana Formation indicate a partial mixture of marine algal with terrestrially-derived organic matter.

Acknowledgements. The author is grateful to Dr. Kh.A. Al-Ani who performed the stable isotope analyses at the Isotopes Laboratory of the University of Missouri, Kansas City (USA) along with the stable isotope specialist team in the ALS Chemex-Global Laboratories. Also I would like to thank M. Al-Dabbas, M.J. Kotarba, an anonymous reviewer and the editor T.M. Peryt for their scientific comments and advice which improved the manuscript.

\section{REFERENCES}

Al-Ankaz, Z.S.A., 2012. Mineralogy, geochemistry and provenance of Dibdibba Formation, south and middle of Iraq. Unpublished M.Sc. thesis, University of Baghdad, College of Science, Department of Geology.

Al-Bassam, K.S., 1984. Economic Geology of Iraq. Final Report on the Regional Geological Survey of Iraq, 5. GEOSURV, Baghdad.

Al-Dabbas, M.A., Awadh, S.A., Abed Zaid, A., 2013. Facies analysis and geochemistry of the Euphrates Formation in Central Iraq. Arabian Journal of Geosciences, DO 10.1007/s12517-013-0932-3

Al-Ghreri, M.F., 1985. Biostratigraphy of the Euphrates Limestone Formation in the Euphrates Valley. Unpublished M.Sc. thesis, College of Science, University of Baghdad.

Al-Hashimi, H.A., Amer, R.M., 1985. Tertiary microfacies of Iraq. D.G., Geological Survey and Mineral Investigation, Baghdad.

Al-Juboury, A.I., 2009. The Upper Miocene Injana (Upper Fars) Formation of Iraq: insights on provenance history. Arabian Journal of Geosciences, 2: 337-364.
Al-Rawi, Y., Sadik, J.M., 1981. Sedimentology of the Dibdibba Clastic formation, Iraq. Journal of Geological Society of Iraq, 14: 55-69.

Andrews, J.E., Greenaway, A.M., Dennis, P.F., 1998. Combined carbon isotope and $\mathrm{C} / \mathrm{N}$ ratios as indicators of source and fate of organic matter in a poorly flushed, tropical estuary: Hunts Bay, Kingston Harbour, Jamaica. Estuarine, Coastal and Shelf Science, 46: 743-756.

Awadh, S.M., Aboud, Z.S., Eisa, M.J., 2013. Chemical and physical control processes on the development of caves in the Injana Formation, Central Iraq. Arabian Journal of Geosciences, 6: 3765-3772.

Bellen, R.C., van, Dunnington, H.V., Wetzel, R., Morton, D., 1959. Lexique stratigraphique internal Asie, Iraq. International Geological Congress. Commission on Stratigraphy, 3, Fasc. 10a.

Berner, R.A., Canfield, D.E., 1989.A new model for atmospheric oxygen over Phanerozoic time. American Journal of Science, 289: 333-361. 
Buday, T., 1980.Stratigraphy and Paleogeography. In: The Regional Geology of Iraq (eds. I.M. Kassab and S.Z. Jassim), 1. Geological Survey and Mineral Investigation, Baghdad.

Buday, T., Jassim, S.Z., 1987. The Regional Geology of Iraq, 2. Tectonism, Magmatism and Metamorphism. GEOSURV, Baghdad.

Burdige, D.J., 2007. Preservation of organic matter in marine sediments: controls, mechanisms, and an imbalance in sediment organic carbon budgets? Chemical Reviews, 107: 467-485

Coplen, T.B., 2011. Guidelines and recommended terms for expression of stable-isotope-ratio and gas-ratio measurement results. Rapid Communications in Mass Spectrometry, 25: 2538-2560.

Cytroky, P., Karim, S.A., 1971. Stratigraphy and Paleontology of the Oligocene and Miocene strata near Anah, Euphrates Valley. NIMCO Report No. CZ 140, SOM. Library, Baghdad.

Eadie, B.J., Chambers, R.L., Gardner, W.S., Bell, G.L., 1984 Sediment trap studies in Lake Michigan: resuspension and chemical fluxes in the southern basin. Journal of Great Lakes Research, 10: 307-321.

Ertel, J.R., Hedges, J.I., 1985. Sources of sedimentary humic substances: vascular plant debris. Geochimica et Cosmochimica Acta, 49: 2097-2107.

Gayara, A.D., Taha, L.S., 1989. Microfacies analysis of the Euphrates Limestone Formation, Northern Iraq. Journal of Geological Society of Iraq, 22: 123-129.

Hassan, K.M., Al-Khateeb, A.A.G., Khlaif, H.O., Kadhum, M.A., Saeed, F.S., 2002. Detailed geological survey for mineral exploration in Karbala-Najaf area. Part 1, Geology. GEOSURV, int. rep. no. 2874

Heaton, T.H.E., 1999. Spatial, species, and temporal variations in the ${ }^{13} \mathrm{C} /{ }^{12} \mathrm{C}$ ratios of $\mathrm{C} 3$ plants: implications for palaeodiet studies. Journal of Archaeological Science, 26: 637-649.

Hedges, J.I., Mann, D.C., 1979. The lignin geochemistry of marine sediments from the southern Washington coast. Geochimica et Cosmochimica Acta, 43: 1809-1818.

Hesslein, R.H., Capel, M.D., Fox, D.E., Hallard, K.A., 1992. Stable isotopes of sulfur, carbon and nitrogen as indicators of trophic level and fish migration in the lower MacKenzie River Basin, Canada. Canadian Bulletin of Fisheries and Aquatic Sciences, 48: 2258-2265

Hu, J., Peng, P., Jia, G., Mai, B., Zhang, G., 2006. Distribution and sources of organic carbon, nitrogen and their isotopes in sediments of the subtropical Pearl River estuary and adjacent shelf, Southern China. Marine Chemistry, 98: 274-285.

Jasper, J.P., Gagosian, R.B., 1993. The relationship between sedimentary organic carbon isotopic composition and organic biomarker compound concentration. Geochimica et Cosmochimica Acta, 57: 167-186.

Jassim, S.Z., Goff, J.C., eds., 2006. Geology of Iraq. Dolin, Prague and Moravian Museum, Brno.

Jassim, S.Z.,Karim, S.A., 1984. Tectonic Framework. Report on the Regional Geological Survey of Iraq, 2. GEOSURV, Baghdad.

Keil, R.G., Tsamakis, E., Fuh, C.B., Giddings, J.C., Hedges, J.I., 1994. Mineralogical and textural controls on organic composition of coastal marine sediments: hydrodynamic separation using SPLITT fractionation. Geochimica et Cosmochimica Acta, 57: 879-893.

Keil, R.G., Tsamakis, E., Giddings, J.C., Hedges, J.I., 1998. Biochemical distributions (amino acids, neutral sugars and lignin phenols) among size-classes of modern marine sediments from the Washington Coast. Geochimica et Cosmochimica Acta, 62 : 1347-1364.

Maksymowska, D., Richard, P., Piekarek-Jankowska, H., Riera, P., 2000. Chemical and isotopic composition of the organic matter sources in the Gulf of Gdansk (Southern Baltic Sea). Estuarine, Coastal and Shelf Science, 51: 585-598.

Meyers, P.A., 1994. Preservation of elemental and isotopic source identification of sedimentary organic matter. Chemical Geology, 114: 289-302.
Meyers, P.A., 1997. Organic geochemical proxies of paleoceanographic, paleolimnologic, and paleoclimatic processes. Organic Geochemistry, 27: 213-250.

Mukhopadhyay, A., Al-Sulaimi, J., Al-Awadi, E., Al-Ruwaih, F., 1995. An overview of the Tertiary geology and hydrogeology of the northern part of the Arabian Gulf region with special reference to Kuwait. Earth-Science Reviews, 40: 259-295.

Muller, A., Voss, M., 1999. The palaeoenvironments of coastal lagoons in the southern Baltic Sea: II. $\delta^{13} \mathrm{C}$ and $\delta^{15} \mathrm{~N}$ ratios of organic matter-sources and sediments. Palaeogeography, Palaeoclimatology, Palaeoecology, 145: 17-32.

Naidu, A.S., Cooper, L.W., Finney, B.P., Macdonald, R.W., Alexander, C., Semiletov, I.P., 2000. Organic carbon isotope ratios $\left(\delta^{13} \mathrm{C}\right)$ of Arctic Amerasian Continental shelf sediments. International Journal of Earth Sciences, 89: 522-532.

Peterson, B., Howarth, R.W., 1987. Sulfur, carbon and nitrogen isotopes used to trace organic matter flow in the salt-marsh estuaries of Sapelo Island, Georgia. Limnology Oceanography, 32: 1195-1213.

Peterson, B.J., Fry, B., 1987. Stable Isotopes in Ecosystem Studies. Annual Review of Ecology and Systematics, 18: 293-320.

Powers, R.W., Ramirez, L.F., Redmond, C.D., Elberg, E.L., 1966. Sedimentary geology of Saudi Arabia. USGS Professional Paper, 560-D

Prahl, F.G., Bennett, J.T., Carpenter, R., 1980. The early diagenesis of aliphatic hydrocarbons and organic matter in sedimentary particulates from Dabob Bay, Washington. Geochimica et Cosmochimica Acta, 44: 1967-1976.

Prahl, F.G., Ertel, J.R., Gon M.A., Sparrow, M.A., Eversmeyer, B. 1994. Terrestrial organic carbon contributions to sediments on the Washington margin. Geochimica et Cosmochimica Acta, 58: 3035-3048.

Prazak, J., 1974. Stratigraphy and Paleontology of the Miocene of the Western Desert, Western Iraq. NIMCO Report. SOM Library.

Premuzic, E.T., Benkovitz, C.M., Gaffney, J.S., Walsh, J.J., 1982 The nature and distribution of organic matter in the surface sediments of world oceans and seas. Organic Geochemistry, 4: 63-77.

Sigman, D.M., Altabet, M.A., Mccorkle, D.C., Francois, R., Fischer, G., 2000. The $\delta^{15} \mathrm{~N}$ of nitrate in the Southern Ocean: Nitrogen cycle and circulation in the ocean interior. Journal of Geophysical Research, 105: 19599-19614.

Stein, R., Macdonald, R.W., eds., 2004.The Organic Carbon Cycle in the Arctic Ocean. Springer, Berlin.

Sweeney, R.E., Liu, K.K., Kaplan, I.R., 1978. Oceanic nitrogen isotopes and their use in determining the source of sedimentary nitrogen. New Zealand. Department of Scientific and Industrial Research Bulletin, 20: 9-26.

Takahashi, K., Yoshioka, T., Wada, E., Sakamoto, M., 1990. Temporal variations in carbon isotope ratio of phytoplankton in a eutrophic lake. Journal of Plankton Research, 12: 799-808.

Tiessen, H., Stewart, J.W.B., Cole, C.V., 1984. Pathways of phosphorus transformations in soils of differing pedogenesis. Soil Science Society of America Journal, 48: 853-858.

Wada, E., 1980. Nitrogen isotope fractionation and its significance in biogeochemical processes occurring in marine environments. In: Isotope Marine Chemistry (eds. E.D. Goldberg, Y. Horibe and K. Saruhashi): 375-398. Uchida Rokakuho, Tokyo.

Wada, E., Terazaki, M., Kabaya, Y., Nemoto, T., 1987. ${ }^{15} \mathrm{~N}$ and ${ }^{13} \mathrm{C}$ abundances in the Antarctic Ocean with emphasis on the biogeochemical structure of the food web. Deep-Sea Research, 34: 829-841.

Wada, E., Kabaya, Y., Kurihara, Y., 1993. Stable isotopic structure of aquatic ecosystems. Journal of Biological Sciences, 18 483-499.

Youkhanna, A.K., 1971. Sedimentary of the Euphrates Formation in Central and Northern Iraq. Unpublished. M.Sc. thesis, College of Science, University of Baghdad. 